\title{
Baicalein, as a Prooxidant, Triggers Mitochondrial Apoptosis in MCF-7 Human Breast Cancer Cells Through Mobilization of Intracellular Copper and Reactive Oxygen Species Generation
}

This article was published in the following Dove Press journal: OncoTargets and Therapy

\author{
Zheng-Hong Liu' \\ Cheng-Xi Yang' \\ Lei Zhang' \\ Cong-Ying Yang ${ }^{\prime}$ \\ Xiu-Quan $X u^{2}$ \\ 'Department of Oncology, The First \\ People's Hospital of Lianyungang, \\ Lianyungang 22206I, People's Republic of \\ China; ${ }^{2}$ School of Pharmacy, Jiangsu \\ University, Zhenjiang 212013, People's \\ Republic of China
}

\begin{abstract}
Background: Baicalein, a natural flavonoid derived from traditional Chinese herb Scutellaria baicalensis Georg (known as Huang Qin in Chinese), has been reported to exhibit notable antitumor activity in various cancer cells, including breast cancer. However, the detailed mechanisms underlying its induced apoptosis as a prooxidant in breast cancer cells are still unknown.
\end{abstract}

Materials and methods: In this study, we investigated the effect of endogenous copper on cytotoxic activity of baicalin against human breast cancer MCF-7 cells in vitro.

Results: Baicalein could remarkably reduce the cell viability in both dose- and timedependent manners in MCF-7 cells but with lower cytotoxic effects on normal breast epithelial cells, MCF-10A. Such cell death could be prevented by pretreatment with $\mathrm{Cu}$ (I)-specific chelator neocuproine (Neo) and reactive oxygen species (ROS) scavengers. Meanwhile, baicalein could induce MCF-7 cell morphological changes, promote apoptotic cell death and increase the apoptotic cell number. Moreover, DCHF-DA staining, flow cytometry and Western blotting analyses proved that baicalein triggered the mitochondrial-dependent apoptotic pathway, as indicated by enhancement the level of intracellular ROS, disruption of mitochondrial membrane potential $(\Delta \Psi \mathrm{m})$, downregulation of anti-apoptotic protein Bcl-2, upregulation of pro-apoptotic protein Bax, release of cytochrome $\mathrm{C}$ and activation of caspase- 9 and caspase-3 in MCF-7 cells. The pretreatment with Neo remarkably weakened these effects of baicalein. Furthermore, we confirmed that the prooxidant action of baicalein involved the direct production of hydroxyl radicals through redox recycling of copper ions.

Conclusion: These findings suggested that baicalein, acting as a prooxidant, could trigger apoptosis in MCF-7 cells occurs via the ROS-mediated intrinsic mitochondria-dependent pathway.

Keywords: baicalein, human breast cancer MCF-7 cells, apoptosis, mitochondria-dependent pathways, prooxidant

\section{Introduction}

Reactive oxygen species (ROS), including hydrogen peroxide $\left(\mathrm{H}_{2} \mathrm{O}_{2}\right)$, superoxide anion radical $\left(\mathrm{O}_{2}{ }^{-}\right)$, hydroxyl radical $(\cdot \mathrm{OH})$ and so on, are mainly produced in the mitochondrial electron transport chain as a consequence of normal metabolism. ${ }^{1}$ Generally, ROS, at low level, can act as signaling molecules to regulate numerous physiological processes, whereas excessive ROS enhancing up to a dangerous level will cause various diseases, such as cardiovascular diseases, diabetes, especially

School of Pharmacy, Jiangsu University,

301, Xuefu Road, Zhenjiang 212013 ,

People's Republic of China

Email xxq781026@ujs.edu.cn 
cancers. ${ }^{2-4}$ Compared to normal cells, cancer cells exhibit significantly enhanced levels of ROS and altered redox status to maintain their malignant phenotypes. $^{5}$ Nevertheless, this biochemical characteristic makes them are more vulnerable to further ROS induced by exogenous ROS-generating agents (prooxidants) than that of normal cells. ${ }^{6,7}$ Based on this intrinsic difference between cancer cells and normal cells, a novel anticancer strategy targeting ROS has been developed, which could selectively kill cancer cells by promoting excess ROS production and inducing mitochondrial dysfunction of cancer cells. ${ }^{8,9}$

Copper is one of the most redox metal ion existed in the chromatin and is closely associated with guanine bases. ${ }^{10}$ Some studies have proved that the copper levels of tissues, serum, and cells are considerably improved in various malignancies. ${ }^{11,12}$ Therefore, cancer cells may be more subject to electron transfer between copper ions and prooxidants to generate excess ROS. Numerous researches have proved that plant polyphenol antioxidants were very easily transformed into prooxidants in the presence of copper ions, leading to the formation of ROS via Fentonlike reaction. Thereafter, these ROS will trigger cellular DNA breakage and consequent cell death. ${ }^{13,14}$ The prooxidant action of these plant polyphenols has been considered to be an important mechanism for their anticancer and apoptosis-inducing properties. ${ }^{15,16}$

Breast cancer is one of the most frequent, primitive malignant tumors in women and has a high probability of metastases and poor prognosis. ${ }^{17}$ In recent years, natural chemical constituents, the alternative chemoprevention agents, have been proved to be effective in treating breast cancer with reduced relapse and decreased serious side effects in comparison with traditional treatment. ${ }^{18}$ Dihydromyricetin, tetrahydrocurcumin and especially baicalein presented significant proliferation inhibition against breast cancer cells through multiple ROSmediated pathways. ${ }^{19-21}$ Just recently, some studies confirmed that baicalein could induce human breast cancer apoptosis via mitochondria- and Caspase-3-dependent pathway. ${ }^{22,23}$ However, to best of our knowledge, its antitumor activity and mitochondria-dependent mechanism aspects as a cupric ion-mediated prooxidant are still unknown. In this study, the in vitro effect of baicalein on MCF-7 human breast cancer cells and its underlying molecular mechanism were investigated systematically. These results provided the evidence that baicalein, as a prooxidant, could induce MCF-7 cells apoptosis through the accumulation of ROS and activation of the mitochondrial apoptotic pathway by mobilizing intracellular copper ions.

\section{Materials and Methods}

\section{Chemicals and Reagents}

Baicalein of $98 \%$ purity by HPLC (CAS No. 491-67-8) was obtained from Aladdin (Shanghai, China) and its $50 \mathrm{mM}$ solutions dissolved in dimethyl sulfoxide (DMSO) were stored at $-20{ }^{\circ} \mathrm{C}$ until used. DMEM/F-12 medium, fetal bovine serum (FBS), $0.25 \%$ trypsin-EDTA, antibiotics (penicillin, streptomycin), DMSO, Catalase (CAT, $3000 \mathrm{U} / \mathrm{mg}$ protein), Superoxide Dismutase (SOD, $6500 \mathrm{U} / \mathrm{mg}$ protein), thiourea (TU), neocuproine (Neo), desferrioxamine mesylate (DM), histidine (His), 3-(4,5-dimethylthiazole)-2,5-diphenyltetrazolium bromide (MTT), Hoechst 33,342, 2',7'-Dichlorodihydrofluorescein diacetate (DCFH-DA), and 5,5',6,6'-Tetrachloro-1,1',3,3'tetraethyl-imidacarbocyanine iodide (JC-1) were purchased from Sigma-Aldrich (St. Louis, MO, USA). Monoclonal antibodies specific for Bcl-2, Bax, Cytochrome C, Caspase-9, Caspase-3, $\beta$-actin, as well as those Horseradish peroxidase-conjugated secondary antibodies were procured from Santa Cruz Biotechnology (Santa Cruz, CA, USA). Annexin V-fluorescein isothiocyanate (FITC)/propidium iodide (Annexin V-FITC/PI) apoptosis detection kit was purchased from Multi Sciences Biotech Co, Ltd (Hangzhou, China). All other chemicals and reagents were of highest purity analytical grade and were obtained from Sigma-Aldrich (St. Louis, MO, USA) until specifically cited.

\section{Cell Lines and Cell Culture}

Human breast cancer cells (MCF-7) and normal breast epithelial cells (MCF-10A) were purchased from the Cell Bank of Shanghai Institute of Biochemistry and Cell Biology, Chinese Academy of Sciences. Cells were cultivated in DMEM/F-12 medium supplemented with $10 \%$ (v/v) FBS, $100 \mathrm{U} / \mathrm{mL}$ penicillin and $100 \mu \mathrm{g} / \mathrm{mL}$ streptomycin at $37{ }^{\circ} \mathrm{C}$ in a humidified atmosphere containing $95 \%$ air and $5 \% \mathrm{CO}_{2}$.

\section{Cell Viability Assay by MTT}

The effect of baicalein on the cell proliferation of MCF-7 and MCF 10A cells was determined by MTT assay. ${ }^{24}$ Briefly, MCF-7 and MCF 10A cells were seeded in 96well plates at a density of $5 \times 10^{3}$ cells per well. Following incubation $24 \mathrm{~h}$, cells were treated with the indicated concentration of baicalein from 12.5 to $200 \mu \mathrm{M}$ for 24 and $48 \mathrm{~h}$. After treatment, $20 \mu \mathrm{L}$ fresh solution of MTT $(5 \mathrm{mg} / \mathrm{mL})$ was added to each well and then incubated for an additional $4 \mathrm{~h}$. Finally, the formed formazan precipitate 
was dissolved in $100 \mu \mathrm{L}$ DMSO and the absorbance was measured at $570 \mathrm{~nm}$ by an ELISA reader (Spectra Max 190, molecular device, USA). The cell viability was calculated as follow: mean absorbance of treated group/mean absorbance of control group $\times 100 \%$.

\section{Hoechst 33,342 Staining}

The fluorescent dye Hoechst 33,342 was used to visualize the nuclear fragmentation, the characteristic of apoptotic cell death. Typically, MCF-7 cells placed into a 6-well plate at a density of $2 \times 10^{5}$ cells per well were coincubated with 50 and $100 \mu \mathrm{M}$ baicalein for $24 \mathrm{~h}$. After washed twice with phosphate-buffered saline (PBS), the cells were stained with $10 \mu \mathrm{g} / \mathrm{mL}$ Hoechst 33,342 for 20 min at $37{ }^{\circ} \mathrm{C}$ in dark. The stained cells were observed under a fluorescent microscope (Leica DM 4000).

\section{Flow Cytometric Analysis of Apoptosis}

Apoptosis detection by flow cytometry was carried out using the Annexin V-FITC Detection Kit. MCF-7 cells were plated in six-well plates and treated with 50 and $100 \mu \mathrm{M}$ of baicalein for $24 \mathrm{~h}$. After incubation, cells were harvested and washed twice with ice-cold PBS and subsequently stained with Annexin V-FITC/ PI according to the manufacturer's instructions. A total of $10^{6}$ cells per sample were collected and immediately analyzed by a FACSCalibur flow cytometer (Becton Dickinson, Franklin Lakes, NJ, USA), and early and late apoptotic cells were expressed as percentage of total number of cells.

\section{Measurements of ROS and Mitochondrial Membrane Potential}

Intracellular redox state was estimated by the levels of intracellular reactive oxygen species (ROS), which was monitored by flow cytometric analysis with DCFH-DA staining as described previously. ${ }^{25}$ Briefly, MCF-7 cells with a density of $2 \times 10^{5}$ cells per well were treated with 50 and $100 \mu \mathrm{M}$ of baicalein for $24 \mathrm{~h}$. Subsequently, the cells were washed twice with PBS and incubated with $10 \mathrm{mM}$ DCFH-DA in dark for $30 \mathrm{~min}$ at $37{ }^{\circ} \mathrm{C}$. Fluorescence intensity was monitored on flow cytometry with excitation and emission settings of 488 and $530 \mathrm{~nm}$, respectively.

Mitochondrial membrane potential $(\Delta \Psi \mathrm{m})$ was monitored as previously reported using the JC-1 stain. ${ }^{26} \mathrm{MCF}-7$ cells were treated with 50 and $100 \mu \mathrm{M}$ of baicalein for $24 \mathrm{~h}$ and then stained with $10 \mu \mathrm{g} / \mathrm{mL} \mathrm{JC}-1$ at $37^{\circ} \mathrm{C}$ for 30 min in dark. Subsequently, the cells were washed and resuspended in PBS, and measured by flow cytometric analysis at excitation and emission wavelengths of $488 \mathrm{~nm}$ and 525/595 nm, respectively. Results were calculated as the ratio (Red/Green) of fluorescence of samples.

\section{Western Blot Analysis of $\mathrm{Bcl}-2$, Bax, Cytochrome C, Caspase-9, Caspase-3 Expression}

Cells were treated with baicalein at a concentration of 50 and $100 \mu \mathrm{M}$ of baicalein for $24 \mathrm{~h}$. Equal protein concentrations of lysate were separated by $12 \%$ SDS-PAGE and then transferred into PVDF membranes. The membrane was pre-incubated with TBS buffer containing 5\% BSA and $0.05 \%$ Tween 20 for $2 \mathrm{~h}$ at room temperature and then blotted with a primary monoclonal antibody (Bcl-2, Bax, Caspase-9, Caspase-3, and $\beta$-actin) overnight at $4^{\circ} \mathrm{C}$, followed by membrane were incubated with appropriate horseradish peroxidase-conjugated secondary antibodies for $1 \mathrm{~h}$. Protein bands were detected by an enhanced chemiluminescence detection kit.

\section{Ultraviolet-Visible Spectroscopy Analysis of Baicalein-Cu (II) System}

Absorption spectra changes associated with baicalein in the presence of $\mathrm{Cu}$ (II) were recorded in the wavelength range of $230 \mathrm{~nm}$ to $600 \mathrm{~nm}$ using a UV-Vis spectrophotometer (UV-2600, Shimadzu Corp., Japan). The spectral tracing was started every appointed time by the addition of $100 \mu \mathrm{M} \mathrm{CuCl}_{2}$ into PBS containing $50 \mu \mathrm{M}$ of baicalein or was started immediately by the addition of increased $\mathrm{CuCl}_{2}$ from 25 to $200 \mu \mathrm{M}$ into $50 \mathrm{mM}$ PBS (pH 7.4) containing $50 \mu \mathrm{M}$ of baicalein.

\section{Detection of Hydroxyl Radical Generation in Baicalein-Cu (II) System}

The analysis of hydroxyl radical's formation was performed by fluorescence technique using terephthalic acid, which readily reacted with hydroxyl radical to produce highly fluorescent products of 2-hydroxyterephthalic acid. $^{27}$ Typical reactions were started by adding $1.0 \mathrm{~mL}$ terephthalic acid (500 $\mu \mathrm{M}$ final concentration) to $2.0 \mathrm{~mL}$ solutions containing $50 \mathrm{mM}$ phosphate buffer ( $\mathrm{pH} 7.4$ ), $100 \mu \mathrm{M} \mathrm{CuCl}_{2}$, and $0,50,100 \mu \mathrm{M}$ baicalein. Reactions were carried out for $30 \mathrm{~min}$ at room temperature and were recorded on a Hitachi F-4500 fluorescence spectrophotometer with excitation setting of $315 \mathrm{~nm}$. 
Additionally, the electron spin resonance (ESR) spectra were used to analyze the hydroxyl radical generation in the baicalein- $\mathrm{Cu}$ (II) system on a Bruker model A300 spectrometer, in which 5,5-dimethyl-1-pyrroline N-oxide (DMPO) was chosen as hydroxyl radical spin-trapping reagents. ${ }^{28}$ The basic system used in this study consisted of 50, 100 $\mu \mathrm{M}$ baicalein, and $50 \mathrm{mM}$ DMPO in $50 \mathrm{mM}$ phosphate buffer solution ( $\mathrm{pH} 7.4)$ at room temperature.

\section{Estimation of DNA and Protein Degradation Induced by Baicalein-Cu (II) System}

The hydroxyl radicals generated in the baicalein-Cu (II) system can directly oxidize DNA and proteins into malonaldehyde (MDA) and carbonyl derivatives. These resultant products can be detected by thiobarbituric acid (TBA) and 2,4-dinitrophenylhydrazine (2,4-DNPH) methods at the characteristic wavelength of 532 and $370 \mathrm{~nm}$, respectively. ${ }^{29,30} \mathrm{In}$ typical reactions, $5 \mathrm{mM}$ of 2-Deoxyribose and $200 \mathrm{mg} / \mathrm{mL}$ of BSA were employed as the substrates and the experimental process was followed with these previously reported carefully.

\section{Statistical Analysis}

Each experiment was done in triplicate and data were expressed as mean $\pm \mathrm{SD}$. The statistical comparisons of the results were performed using ANOVA and two-tailed Student's $t$-test. Statistical significance was defined as a ${ }^{*} p<0.05$.

\section{Results}

\section{Baicalein Selectively Inhibited Breast Cancer Cell Proliferation}

Firstly, MTT assay was performed to evaluate the antiproliferative effect of baicalein on MCF-7 and MCF- 10A cells. As shown in Figure 1A and B, baicalein could significantly inhibit MCF-7 cells growth in both doseand time-dependent manners with the $\mathrm{IC}_{50}$ values of $85.07 \pm 1.26 \mu \mathrm{M}$ for $24 \mathrm{~h}$ and $57.41 \pm 1.15 \mu \mathrm{M}$ for $48 \mathrm{~h}$, respectively. Pretreatment with $100 \mu \mathrm{M} \mathrm{CuCl}_{2}$ induced a clear enhancement in cytotoxicity against MCF-7 cells. However, baicalein presented little cytotoxicity to normal breast epithelial cells, MCF-10A with higher $\mathrm{IC}_{50}$ values of $556.98 \pm 7.34 \mu \mathrm{M}$ and $530.17 \pm 8.65 \mu \mathrm{M}$, correspondingly, even at the concentration up to $100 \mu \mathrm{M}$ with or without $100 \mu \mathrm{M} \mathrm{CuCl}_{2}$ pretreatment (Figure 1C and D). This is an evidence that baicalein is selectively cytotoxic to MCF-7 rather than MCF-10A cells. Based on the MTT results, two concentration levels of 50 and $100 \mu \mathrm{M}$ were selected for further experiments.

To further determine the role of copper ions on baicalein against MCF-7 cells proliferation, the effects of various metal ion chelators and scavengers of ROS were investigated. When MCF-7 cells were treated with baicalein in the presence of $\mathrm{Cu}$ (I)-specific chelator Neo, instead of ironspecific chelator DM or zinc-specific chelator His, the antiproliferative activity was remarkably restrained (Figure 2A). Meanwhile, all three ROS scavengers including SOD, CAT and $\mathrm{TU}$ were responsible for the decreasing baicaleininduced cytotoxicity on MCF-7 cells (Figure 2B). These results suggest that the redox cycling of intracellular $\mathrm{Cu}$ (II) and formation of ROS act as synergistic effectors in the pathway that leads to MCF-7 cells growth inhibition by baicalein.

\section{Baicalein Induced MCF-7 Cells Apoptosis}

Subsequently, the morphological changes of MCF-7 cells in response to baicalein treatment were visualized by fluorescent microscopy after being stained by Hoechst 33,342. MCF-7 cells treated by 50 and $100 \mu \mathrm{M}$ of baicalein displayed a specific characteristic morphologic change of apoptosis, including condensation of chromatin, nuclear fragmentation and apoptotic body formation along with a clear reduction in the number of living cells compared with the control (Figure 3A-C). However, using Neo pretreatment could remarkably reverse these changes (Figure 3D).

For further confirmation, the cell death mechanism, MCF-7 cells treated with baicalein were double stained by Annexin-V FITC/PI and followed by flow cytometry detection. The results shown in Figure 4 revealed that the proportion of apoptotic MCF-7 cells were significantly increased following treatment with 50 and $100 \mu \mathrm{M}$ of baicalein. Noticeably, pretreatment with Neo strongly reduced the percentage of cells in apoptosis.

These data together strongly reaffirmed that the role of intracellular copper is involved in the process of apoptosis on MCF-7 cells induced by baicalein.

\section{Baicalein Induced ROS Generation and Decreased the Level of Mitochondrial Membrane Potential in MCF-7 Cells}

It has been reported that intracellular accumulation of ROS and the loss of mitochondrial membrane potential $(\Delta \Psi \mathrm{m})$ are crucial processes in mitochondrial-dependent apoptosis in cancer cells. ${ }^{31-33}$ Thus, we further measured the 

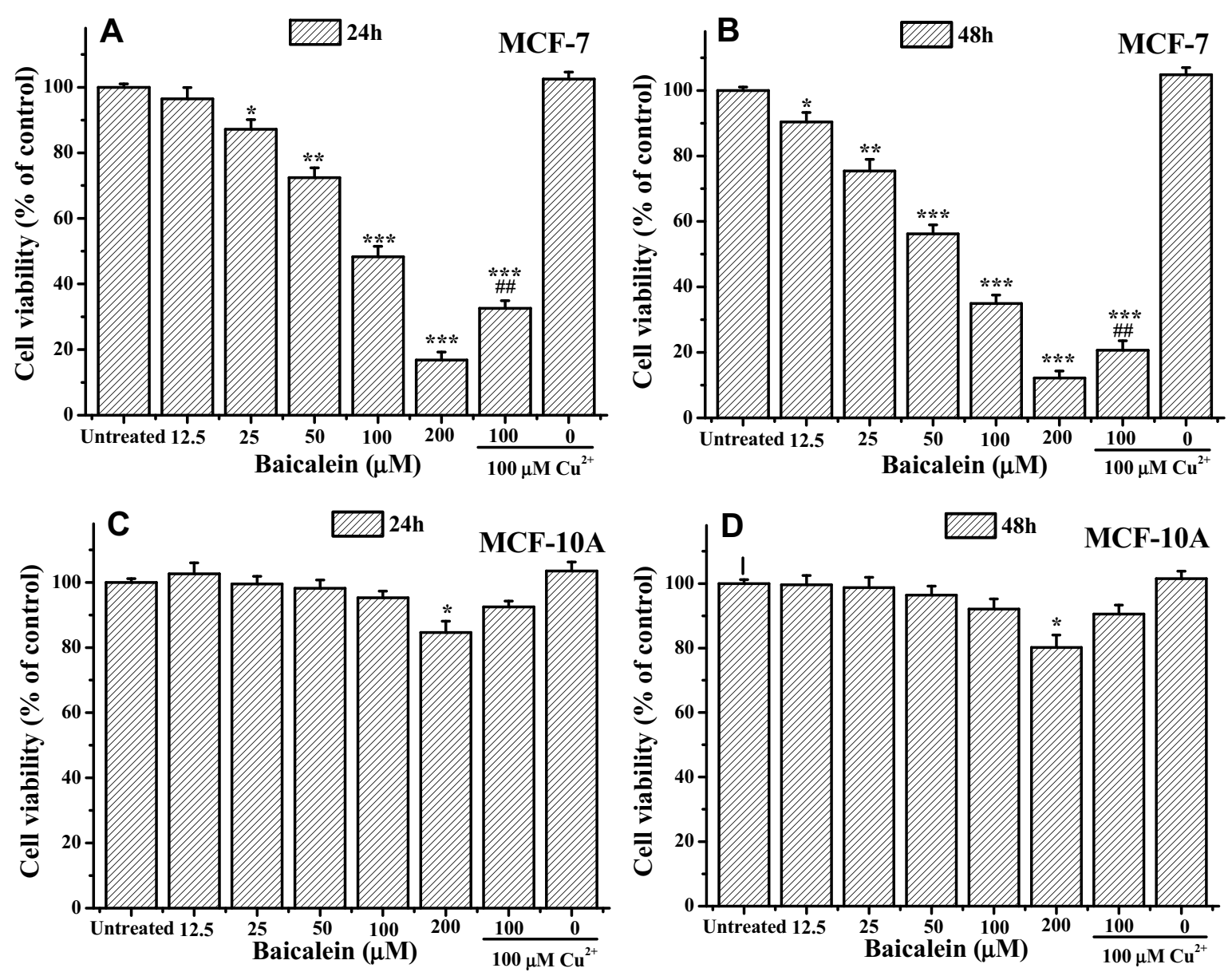

Figure I Baicalein selectively inhibits cell proliferation in breast cancer cell line MCF-7 and normal breast epithelial cell line MC-I0A.Notes: MCF-7 cells were treated with indicated concentrations of baicalein with or without $\mathrm{CuCl}_{2}$ pretreatment for (A) $24 \mathrm{~h}$ and (B) $48 \mathrm{~h}$, and MCF-I0A cells for (C) $24 \mathrm{~h}$ and (D) $48 \mathrm{~h}$, respectively. All data were expressed as the means $\pm S D$ of values from triplicate experiments. $* P<0.05$, ${ }^{*} * P<0.01$ and $* * * P<0.00$ I versus untreated group; ${ }^{\#} P<0.0$ I for the significance between the groups with or without $\mathrm{CuCl}_{2}$ pretreatment.
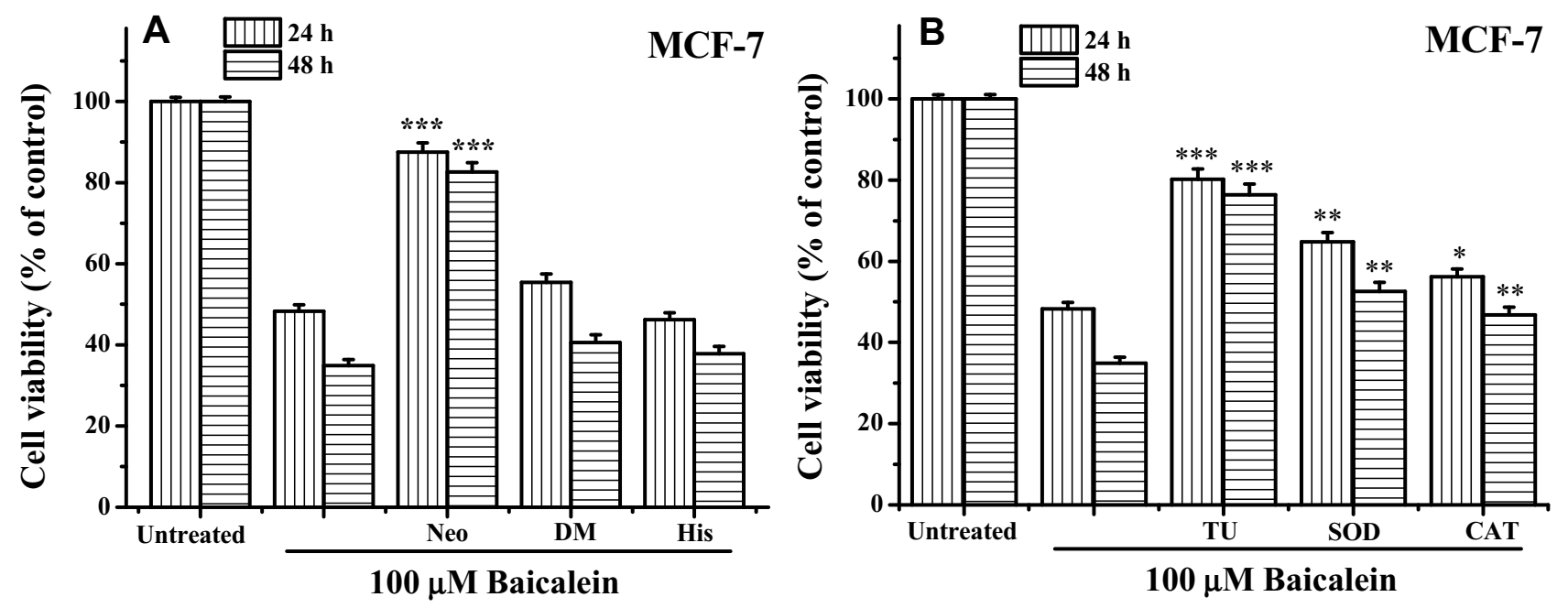

Figure 2 Effects of chelators and scavengers of ROS on MCF-7cells proliferation inhibition induced by baicalein.Notes: MCF-7 cells were treated with I00 $\mu$ M of baicalein either alone or in the presence of $\mathrm{Neo}$, DM, and His for $2 \mathrm{~h}$ with the same concentration of $100 \mu \mathrm{M}(\mathbf{A})$, or in the presence of different ROS scavengers, namely TU ( 500 $\mu \mathrm{M})$, SOD $\left(100 \mu \mathrm{g} \mathrm{mL}^{-1}\right)$ and CAT $\left(100 \mu \mathrm{g} \mathrm{mL}^{-1}\right)(B)$ for $24 \mathrm{~h}$ and $48 \mathrm{~h}$, respectively. All data were expressed as the means \pm SD of values from triplicate experiments. $* P<0.05, * * P<0.01$ and $* * * P<0.00$ I for the significance between the groups with or without pretreatment. 

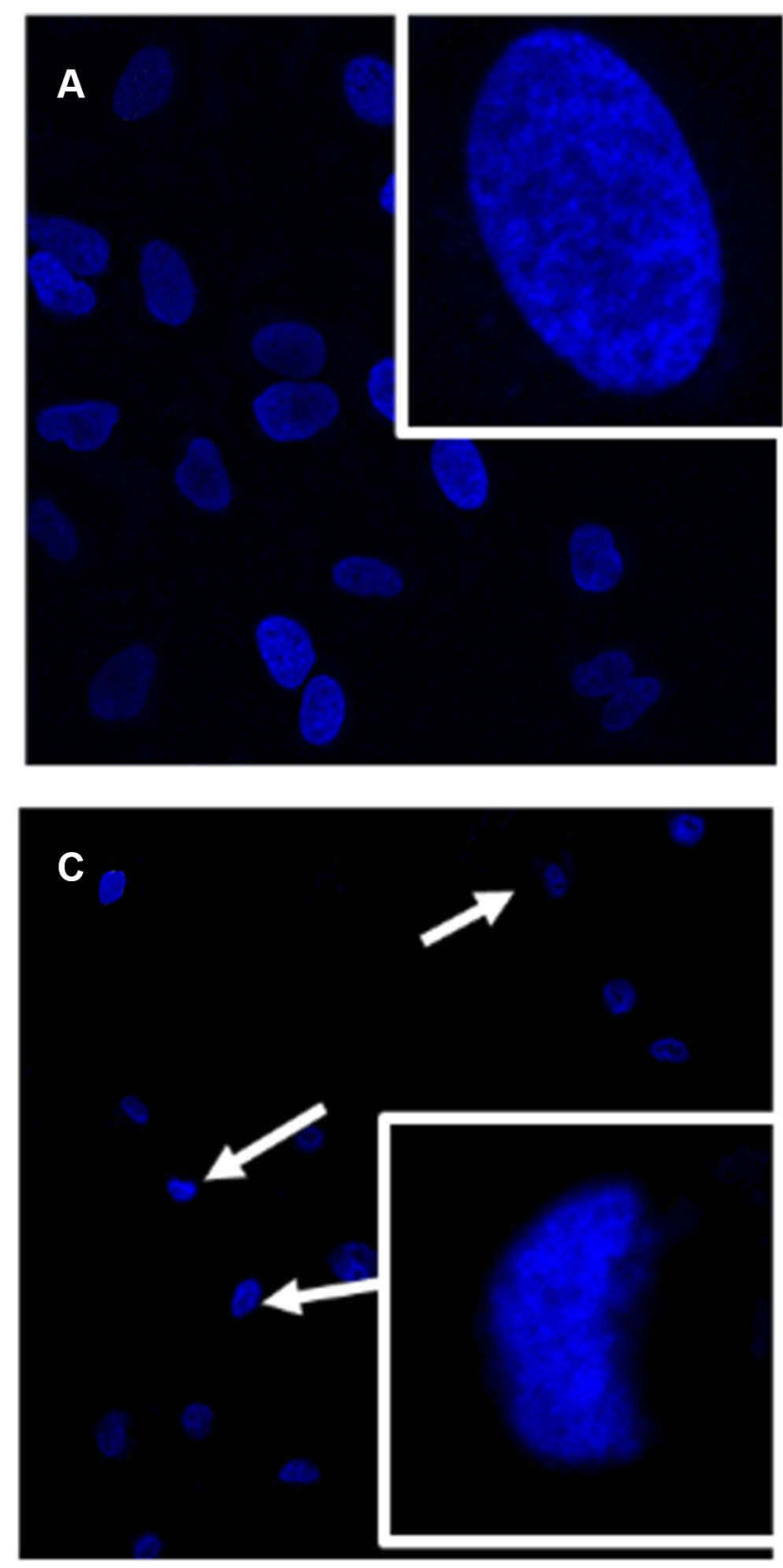

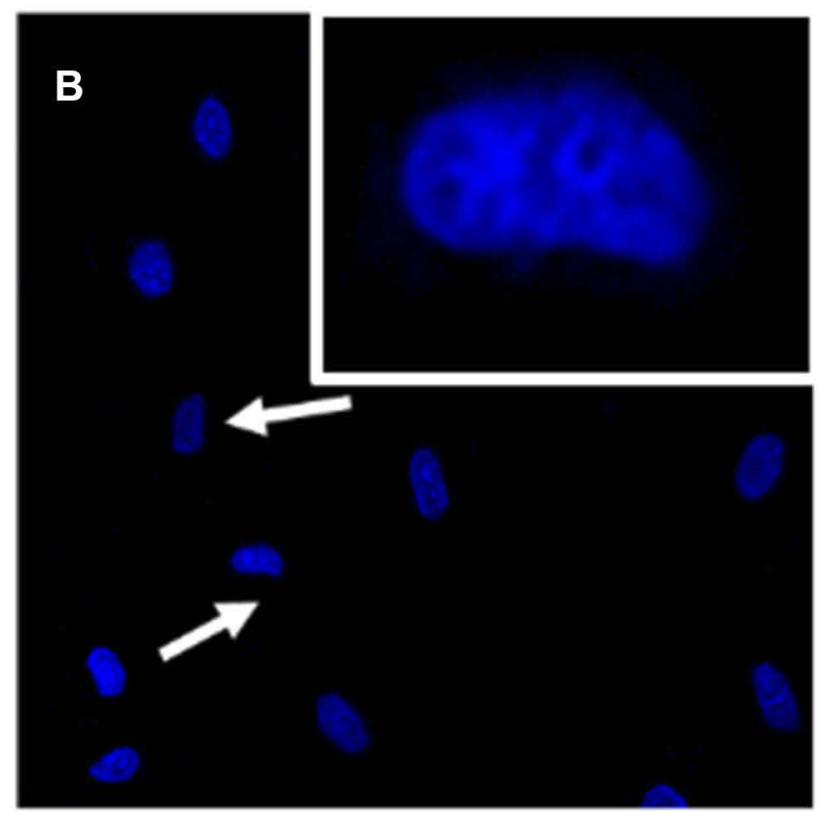

D

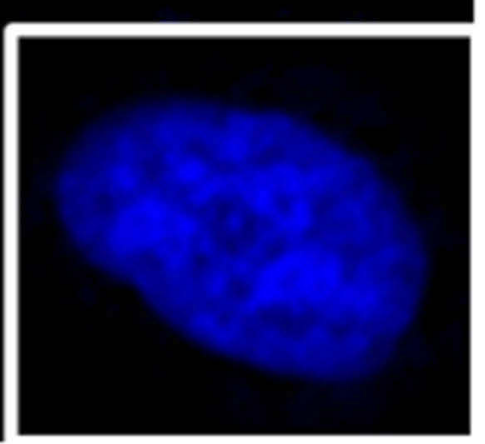

Figure 3 Apoptotic morphological changes of MCF-7 cells were detected by Hoechst 33,342 staining.Notes: MCF-7 cells were incubated with 0 (A), 50 (B), $100 \mu M($ C) of baicalein alone or $100 \mu \mathrm{M}$ of baicalein in the presence of $\mathrm{Neo}(100 \mu \mathrm{M})$ pretreatment (D) for $24 \mathrm{~h}$, respectively. The arrow indicated the cells with the typical characteristics of apoptosis.

intracellular ROS levels of MCF-7 cells by DCFH-DA staining with or without treatment by baicalein. The results (Figure 5A and B) exhibited that baicalein caused a substantial increase in the ROS levels in a dosedependent fashion with a 1.36 and 1.51-folds increased relative to the control with 50 and $100 \mu \mathrm{M}$ treatment for $24 \mathrm{~h}$, respectively. Similarly, the increased DCF fluorescence in the cells treated with $100 \mu \mathrm{M}$ of baicalein was significantly reversed by the Neo pretreatment. The effect of baicalein on the mitochondria membrane function was also evaluated in MCF-7 cells by measuring $\triangle \Psi \mathrm{m}$ stained with JC-1, and the changes of $\Delta \Psi \mathrm{m}$ were analyzed by flow cytometry. Baicalein alone at 50 , and $100 \mu \mathrm{M}$ could enhance the loss of $\triangle \Psi \mathrm{m}$ of MCF-7 cells compared to the untreated group, whereas, pretreatment of Neo could significantly inhibit the $\Delta \Psi \mathrm{m}$ loss induced by baicalein (Figure $5 \mathrm{C}$ ).

These results were clearly indicated that the increased ROS and disruption of the mitochondrial membrane were 

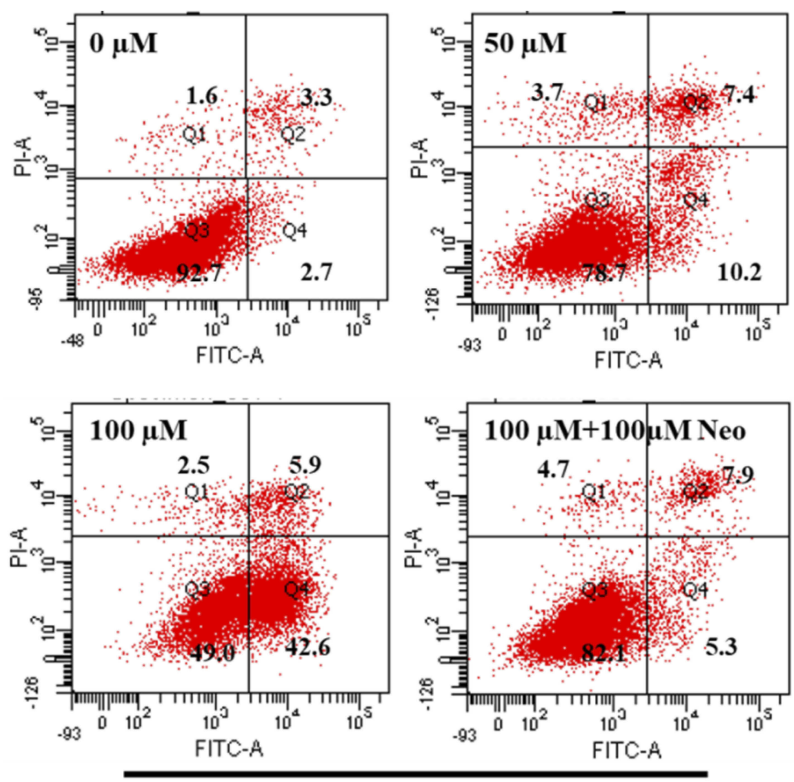

Baicalein

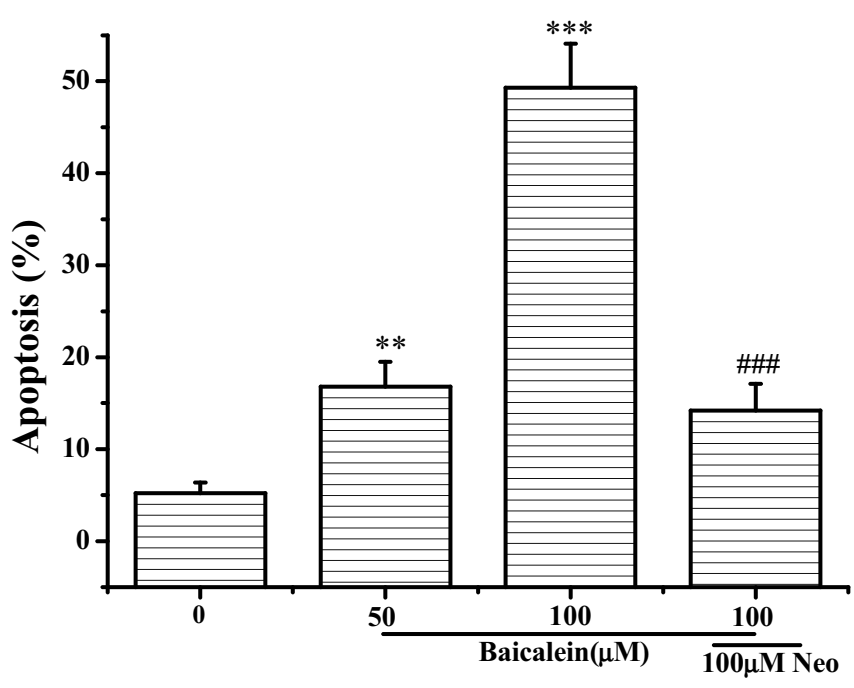

Figure 4 Baicalein induced apoptosis in MCF-7 cells.Notes: MCF-7 cells were treated with $0,50,100 \mu M$ of baicalein alone and I00 $\mu$ M of baicalein in the presence of Neo $(100 \mu \mathrm{M})$ pretreatment for $24 \mathrm{~h}$ before the cells were double stained with Annexin V/PI and followed by flow cytometric analysis. All data were expressed as the means \pm SD of values from triplicate experiments. ${ }^{* * P} P 0.01$ and $* * * P<0.001$ versus untreated group; ${ }^{* \#} P<0.00$ I for the significance between the groups with or without Neo pretreatment.

mainly produced by the prooxidative activity of baicalein though mobilization of intracellular copper during apoptosis process of MCF-7 cells.

\section{Baicalein Activated the Mitochondrial Apoptotic Pathway in MCF-7 Cells Apoptosis}

To reveal the underlying mechanism of baicalein as a prooxidant on inducing apoptosis in MCF-7 cells via mitochondrial apoptotic pathway, we further quantitated the expression of the mitochondrial apoptotic pathwayassociated proteins by Western blotting analysis. Baicalein treatment induced a significant improving expression of the pro-apoptotic protein Box and the cleaved forms of caspase- 3 and caspase- 9 together with the increased release of Cytochrome $\mathrm{C}$ into cytoplasm. However, the expression of anti-apoptotic proteins Bcl-2 declined gradually with the increase of baicalein (Figure 6A and B). Meanwhile, MCF-7 cells were pretreated with $100 \mu \mathrm{M}$ Neo before exposure to $100 \mu \mathrm{M}$ baicalein, these phenomena were effectively suppressed. These results further indicated that baicalein induces caspase-dependent apoptosis in MCF-7 cells via triggering the mitochondria-dependent signaling pathway by mobilizing the intracellular copper.

\section{Formation of Baicalein-Cu Complex and the Generation of Hydroxyl Radicals}

Based on the above observations, the activity of baicalein on inducing apoptosis of MCF-7 cells is mainly attributed to its prooxidant activity by mobilizing intracellular copper ions. To probe the detailed chemical mechanisms of synergistic effect between baicalein and $\mathrm{Cu}$ (II), the interaction of baicalein with $\mathrm{Cu}$ (II) was firstly analyzed by UV-Vis spectroscopy. The result (Figure 7A) indicated that the increasing in $\mathrm{Cu}$ (II) concentration caused a linear decrease in the absorbance at the maximal absorption of $367 \mathrm{~nm}$ until reached and saturated at $100 \mu \mathrm{M}$ of $\mathrm{Cu}$ (II), which indicated that $1 \mathrm{~mol}$ of baicalein is able to chelate 2 mol of copper ions. Meanwhile, addition of $100 \mu \mathrm{M} \mathrm{Cu}$ (II) to the baicalein solution induced a rapid decrease of absorbance at $367 \mathrm{~nm}$ with time (Figure 7B). The change of absorption spectra suggests an occurrence of electron transfer between baicalein and copper ions. ${ }^{7}$

It has been previously reported that during the reduction of $\mathrm{Cu}$ (II) to $\mathrm{Cu}(\mathrm{I})$, ROS such as hydroxyl radicals are formed. ${ }^{34,35}$ Therefore, the capacity of baicalein to generate ROS in the presence of $\mathrm{Cu}$ (II) was examined. The dosedependent generation of hydroxyl radicals by baicalein as evidenced by the increase in fluorescence intensity and EPR signals are observed (Figure 8A and B). These results are in 
A
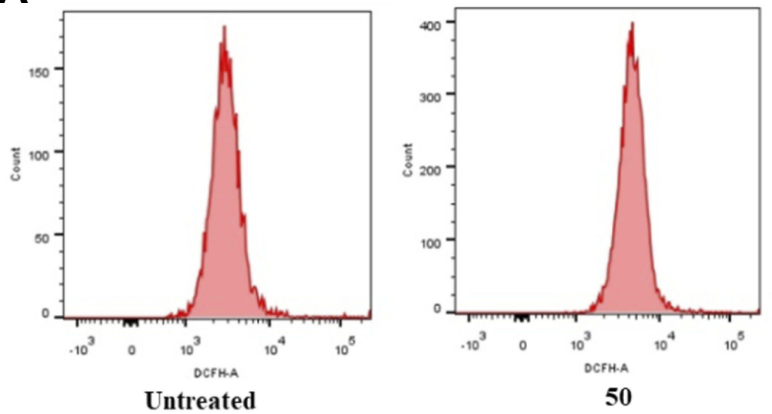

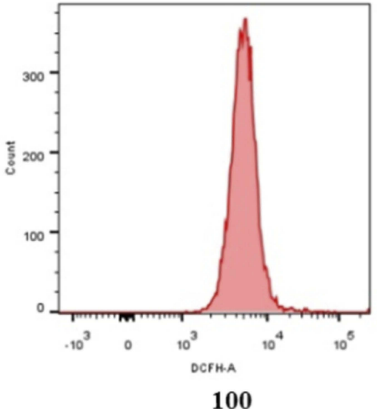

Baicalein $(\mu \mathrm{M})$

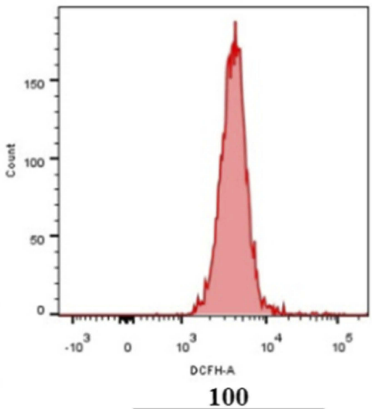

Neo
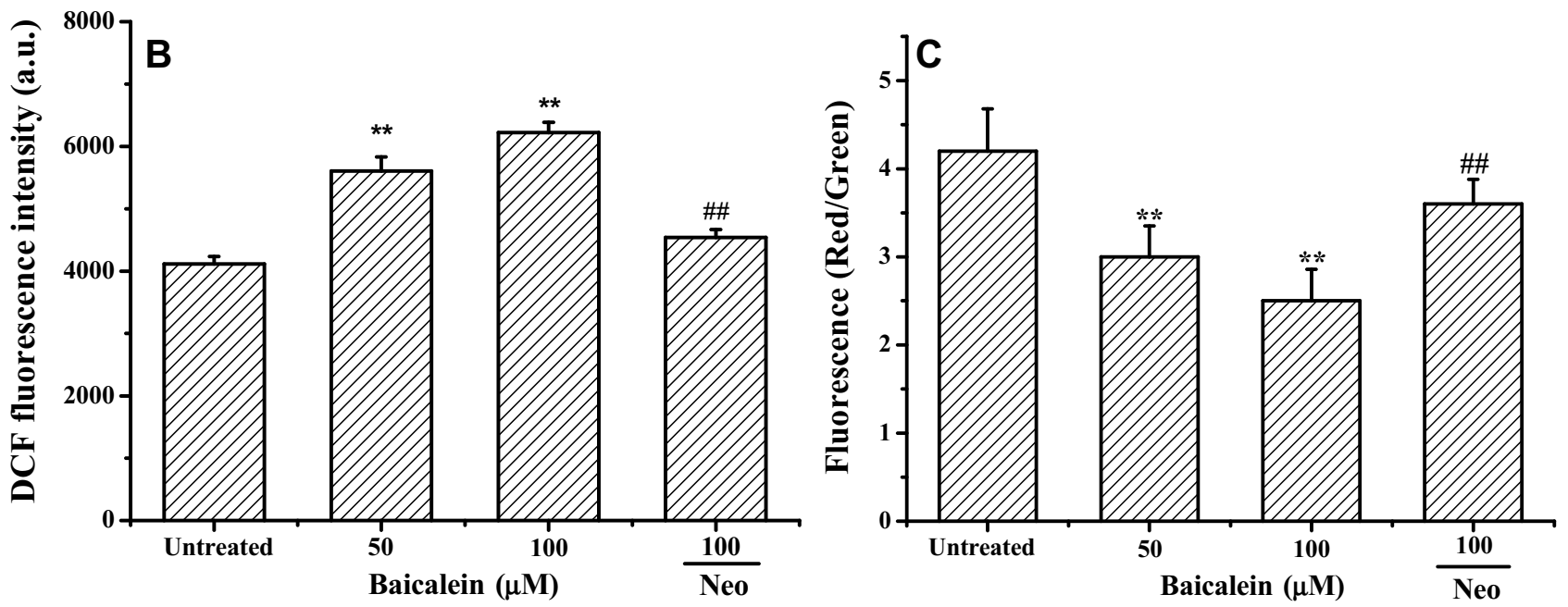

Figure 5 Baicalein induced intracellular ROS generation and mitochondrial membrane potential collapse on MCF-7 cells.Notes: MCF-7 cells were treated with 0, 50 and $100 \mu \mathrm{M}$ of baicalein alone or $100 \mu \mathrm{M}$ of baicalein in the presence of Neo $(100 \mu \mathrm{M})$ pretreatment for $24 \mathrm{~h}$. (A and B) ROS generation was assessed by DCHF-DA staining and flow cytometry, (C) $\Delta \Psi \mathrm{m}$ changes were monitored by loading with JC-I and analyzed by flow cytometry. All data were expressed as the means \pm SD of values from triplicate experiments. ${ }^{* * P}<0.01$ versus untreated group; ${ }^{\#} P<0.0$ I for the significance between the groups with or without Neo pretreatment.

further support that the prooxidant action of baicalein involves the reduction of $\mathrm{Cu}$ (II) to $\mathrm{Cu}$ (I), and the consequent generation of hydroxyl radicals.

The generated ROS in baicalein-Cu (II) system was further determined its behavior of leading to DNA and protein degradation. As seen in Figure 9, the results clearly exhibited that the increasing concentrations of baicalein resulted in a progressive increase in the formation of MDA and carbonyl groups. This growth is similarly inhibited by the addition of Neo and TU.

\section{Discussion and Conclusions}

Natural products have attracted considerable attention in recent years due to its effective treatment outcomes in relation to human diseases. Polyphenols, present ubiquitously in the plant kingdom including fruits and vegetables, are a class of plant secondary metabolites possessing a wide range of pharmacological properties including anticancer, the mechanisms of which have been the subject of considerable interest. Recent investigations have documented that polyphenols with good antioxidant activity may exhibit pro-oxidant activity in the presence of copper ions, which can induce apoptosis in various cancer cell lines but not in normal cells. ${ }^{36,37}$ Such a mechanism for the cytotoxic action of these compounds against cancer cells would involve mobilization of endogenous copper ions, generating ROS and the consequent prooxidant action. $^{38}$

Recently, though several researches have described that baicalein effectively suppressed growth and induced apoptosis in human breast cancer, ${ }^{22,23}$ a clear underlying molecular mechanism for the effects of baicalein as a prooxidant has not been elucidated. Therefore, in the present study, we focused on exploration of the cellular, molecular and chemical changes associated with cytotoxicity, caused due prooxidant activity of 
A

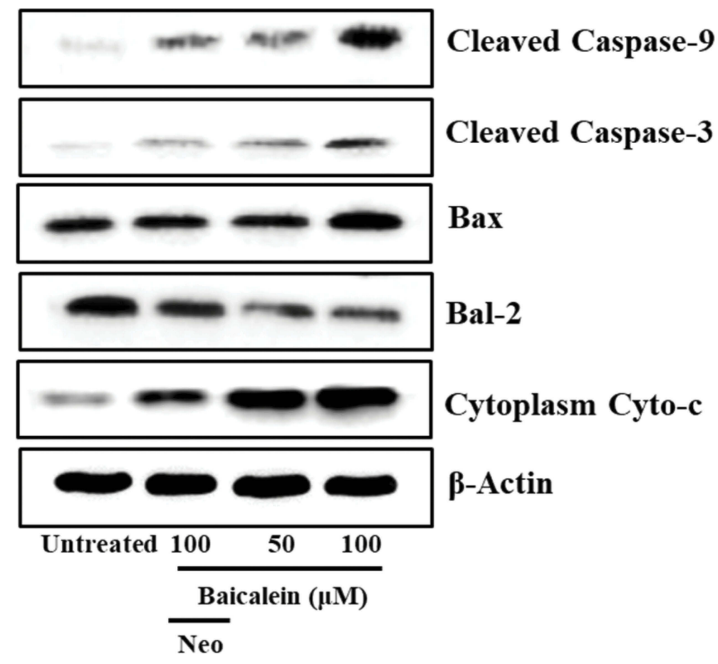

B

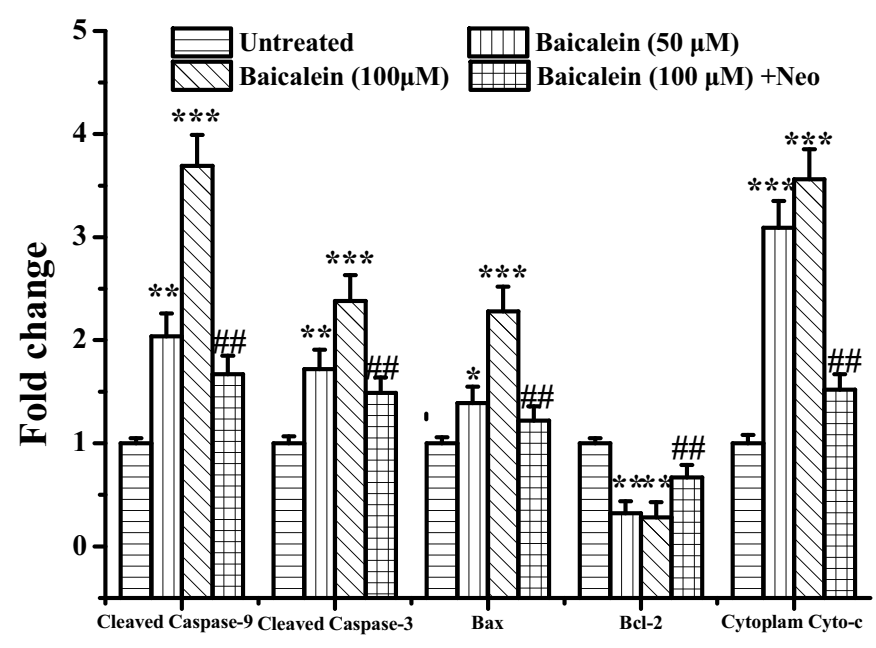

Figure 6 Baicalein affects apoptosis-associated protein expression in MCF-7 cells.Notes: (A and B) MCF-7 cells were treated with 50 and $100 \mu M$ of baicalein alone or 100 $\mu \mathrm{M}$ of baicalein in the presence of $\mathrm{Neo}(100 \mu \mathrm{M})$ pretreatment for $24 \mathrm{~h}$ and then the apoptosis-associated protein was examined by Western blotting analysis. All data were expressed as the means \pm SD of values from triplicate experiments. ${ }^{*} P<0.05, * * P<0.0 \mathrm{I}$ and $* * * P<0.00 \mathrm{I}$ versus untreated group; ${ }^{\#} P<0.0 \mathrm{I}$ for the significance between the groups with or without Neo pretreatment.
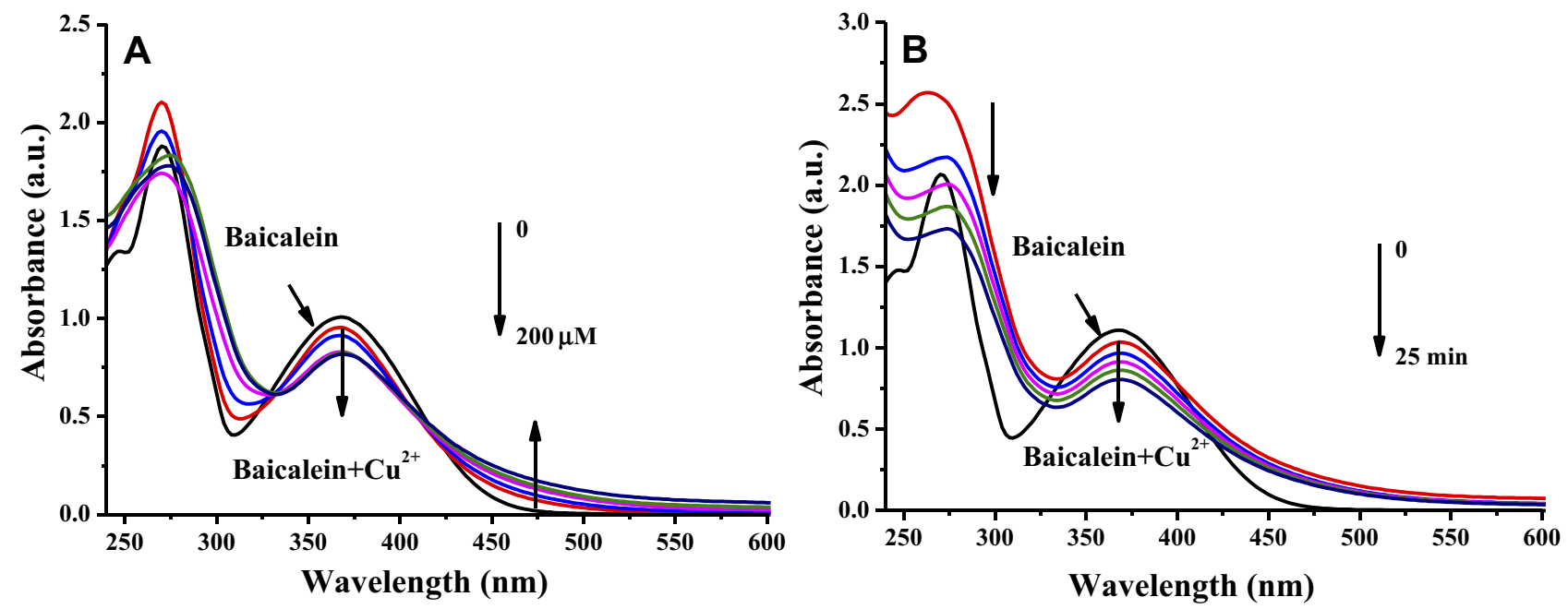

Figure 7 Absorption spectral changes of baicalein-Cu complex system.Notes: (A) $50 \mu \mathrm{M}$ baicalein in the presence of several concentration of Cu (II) (zero to $200 \mu \mathrm{M})$ in $50 \mathrm{mM}$ phosphate buffer ( $\mathrm{pH}$ 7.4). (B) $50 \mu \mathrm{M}$ baicalein in the presence of $100 \mu \mathrm{M} \mathrm{Cu}$ (II) with 5 min intervals in $50 \mathrm{mM}$ phosphate buffer (pH 7.4).

baicalein in human breast cancer MCF-7 cells in vitro. Our results clearly indicated that baicalein effectively inhibits MCF-7 cells proliferation at both dose and time-depended manner. We also observed that baicalein displayed minimal toxicity on normal breast epithelial MCF-10A cells (Figure 1). This observed resistance can in part be explained by the undetectable levels of copper present in MCF-10A cells. ${ }^{39}$ Meanwhile, pre-incubating MCF-7 cells with Neo or ROS scavengers significantly reverse the cytotoxicity effect of baicalein, and this reduction in cytotoxicity is coupled to a significant reduction in the levels of ROS generated (Figure 5A and B). These results suggest the involvement of endogenous copper, and $\mathrm{Cu}(\mathrm{I})$ as an internal element, in the pathway that leads to MCF-7 cells growth inhibition by baicalein.

It is known that the mitochondria-mediated apoptosis is an important-targeted ROS pathway for regulating cancer cell apoptosis. In the classic mitochondria-mediated apoptotic pathway, relevant studies confirmed that a high Bax/ $\mathrm{Bcl}-2$ ratio (pro-apoptotic protein/anti-apoptotic protein) is 

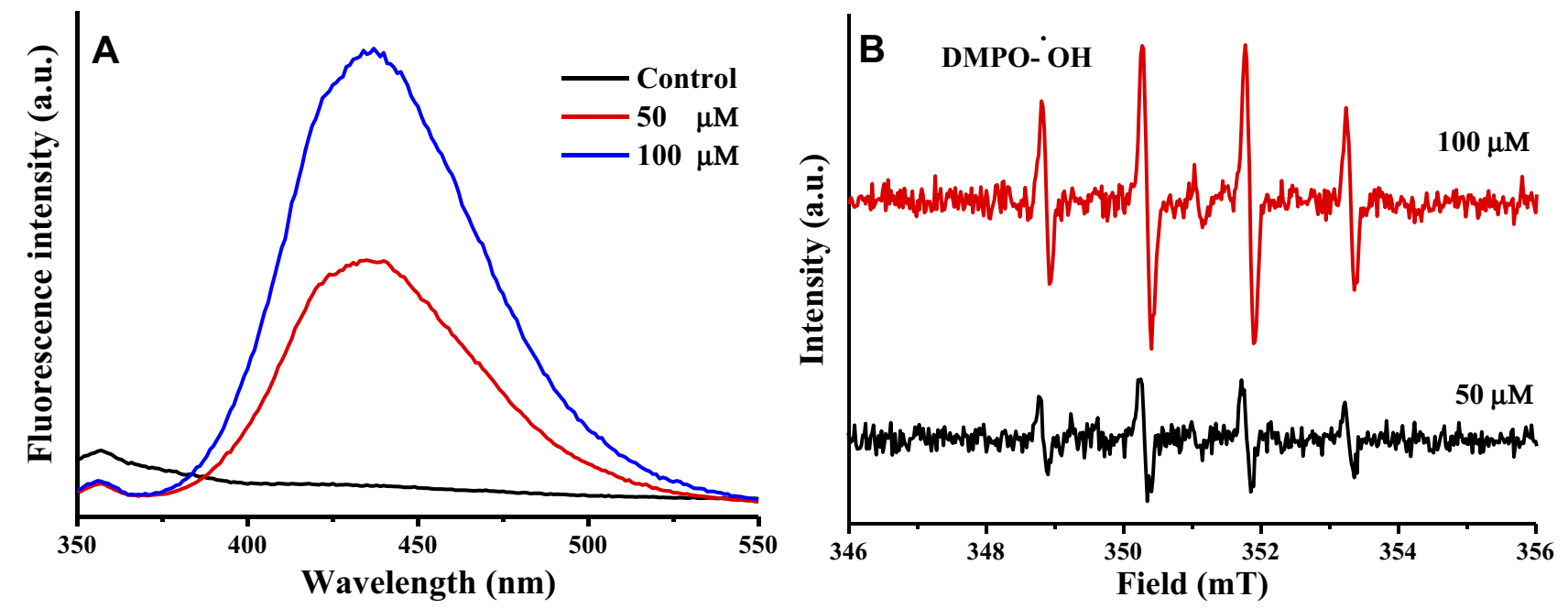

Figure 8 Formation of a hydroxyl radicals of baicalein in the presence of Cu (II).Notes: (A) Hydroxyl radical formation was measured by determining the generated 2-hydroxyterephthalic acid as a result of the reaction between terephthalic acid and hydroxyl radicals. (B) Hydroxyl radical formation was measured by determining the signal response of the DMPO-OH by ESR spectrometer.
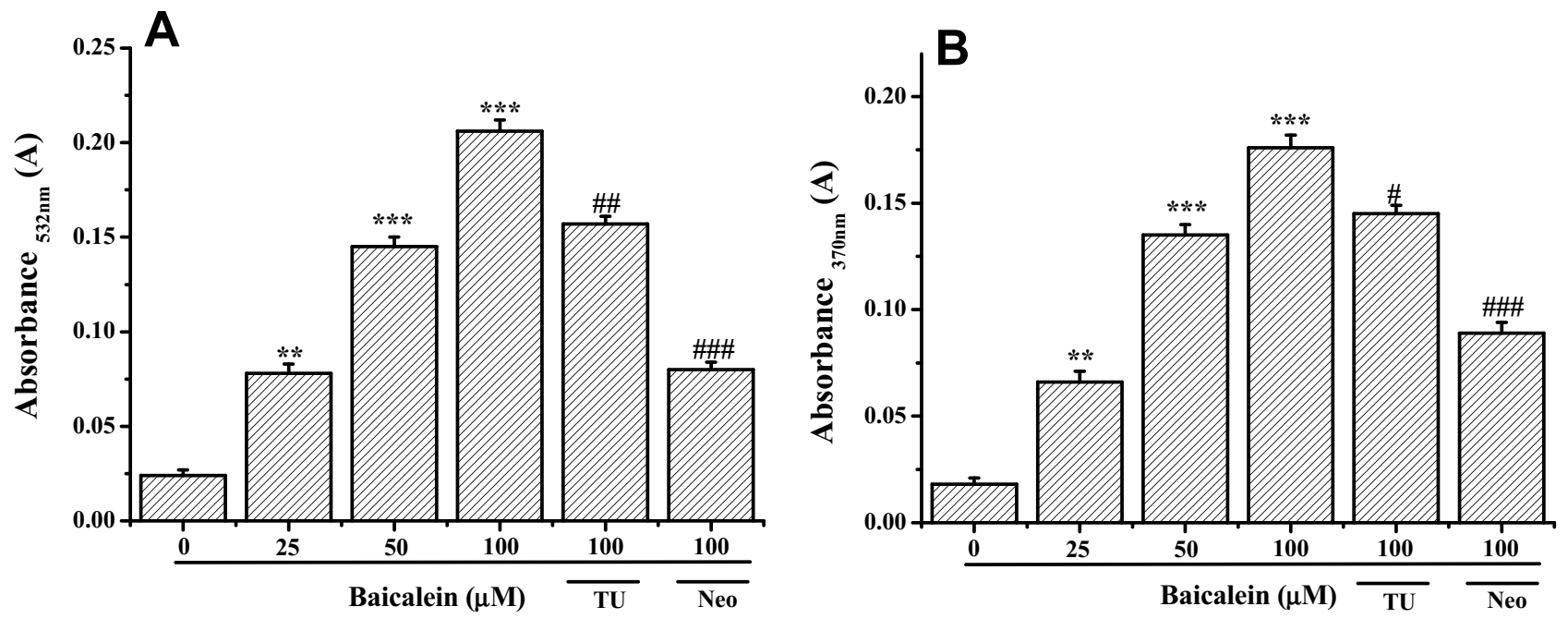

Figure 9 Formation of MDA and carbonyl groups of baicalein in the presence of $\mathrm{Cu}$ (II).Notes: (A) Reaction mixture (2.0 mL) contained $50 \mathrm{mM}$ phosphate buffer ( $\mathrm{pH} 7.4)$, ImM 2-Deoxyribose, $100 \mu \mathrm{M} \mathrm{Cu}$ (II) and indicated concentration of baicalein. The reaction mixture was incubated at $37^{\circ} \mathrm{C}$ for 120 min. MDA formation was measured by determining the TBA reactive material. (B) Reaction mixture $(2.0 \mathrm{~mL})$ contained $50 \mathrm{mM}$ phosphate buffer ( $\mathrm{pH} 7.4), 2 \mathrm{mg} \mathrm{mL}^{-1} \mathrm{BSA}, 100 \mu \mathrm{M}$ Cu (II) and indicated concentration of baicalein. The reaction mixture was incubated at $37^{\circ} \mathrm{C}$ for $30 \mathrm{~min}$. Carbonyl groups formation was measured by determining the DNPH reactive material. All data were expressed as the means \pm SD of values from triplicate experiments. ${ }^{* *} P<0.01$ and ${ }^{* * *} P<0.00$ Iversus untreated group; ${ }^{\#} P<0.05$, ${ }^{\# \#} P<0.01$ and ${ }^{\# \#} P<0.001$ for the significance between the groups with or without Neo and TU pretreatment.

associated with the decrease in mitochondrial membrane integrity and Cytochrome $\mathrm{c}$ release from mitochondria to cytosols. ${ }^{40,41}$ The facilitated release of cytochrome $\mathrm{C}$ act as an apoptogenic factor to activates caspase-9 and caspase-3, which finally leads to apoptosis. ${ }^{42}$ In this present study, following treatment with baicalein, we also observed an increase in intracellular ROS levels and a notable dissipation of $\Delta \Psi \mathrm{m}$, a significant decrease in the expression of Bcl-2 and increase in the expression of
Bax, Caspase-9 and Caspase-3 along with the increased release of Cytochrome $\mathrm{C}$ (Figure 6). The importance of this pathway was further confirmed by pretreatment with Neo, which significantly prevented baicaleininduced cell apoptosis. Taken together, these results strongly suggest that baicalein induces MCF-7 cells apoptosis through the accumulation of ROS and mitochondrial apoptotic pathway via mobilization of intracellular copper. 
<smiles>O=c1cc(-c2ccccc2)oc2cc(O)c(O)c(O)c12</smiles>
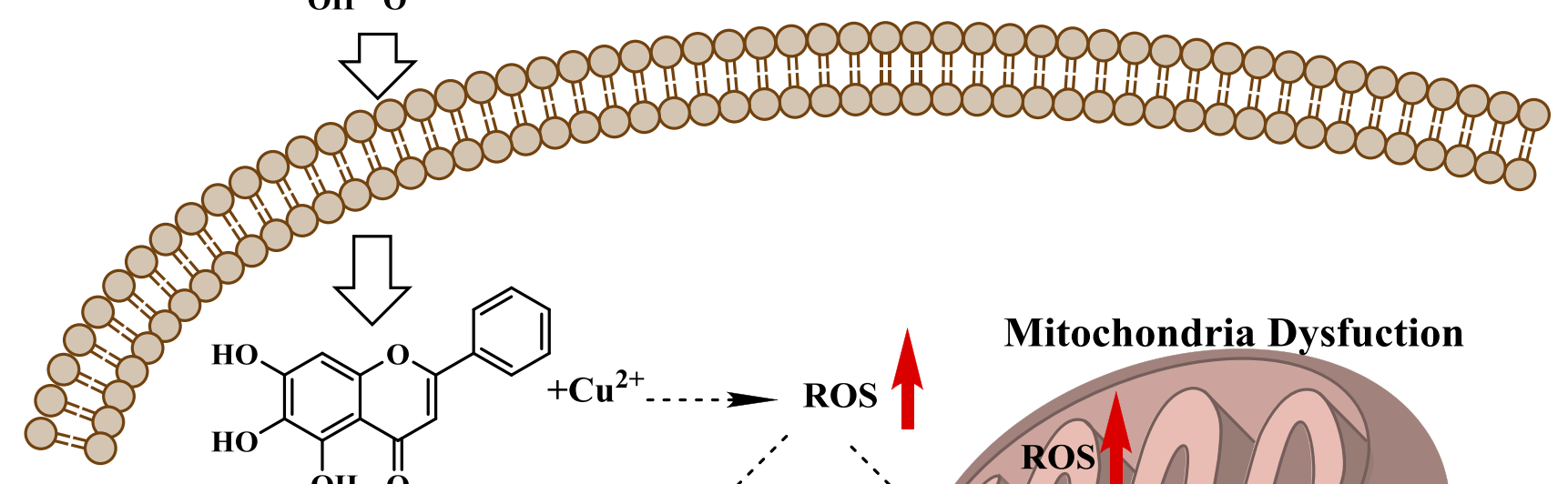<smiles>O=c1cc(/C=C/I)oc2cc(O)c(O)c(O)c12</smiles>
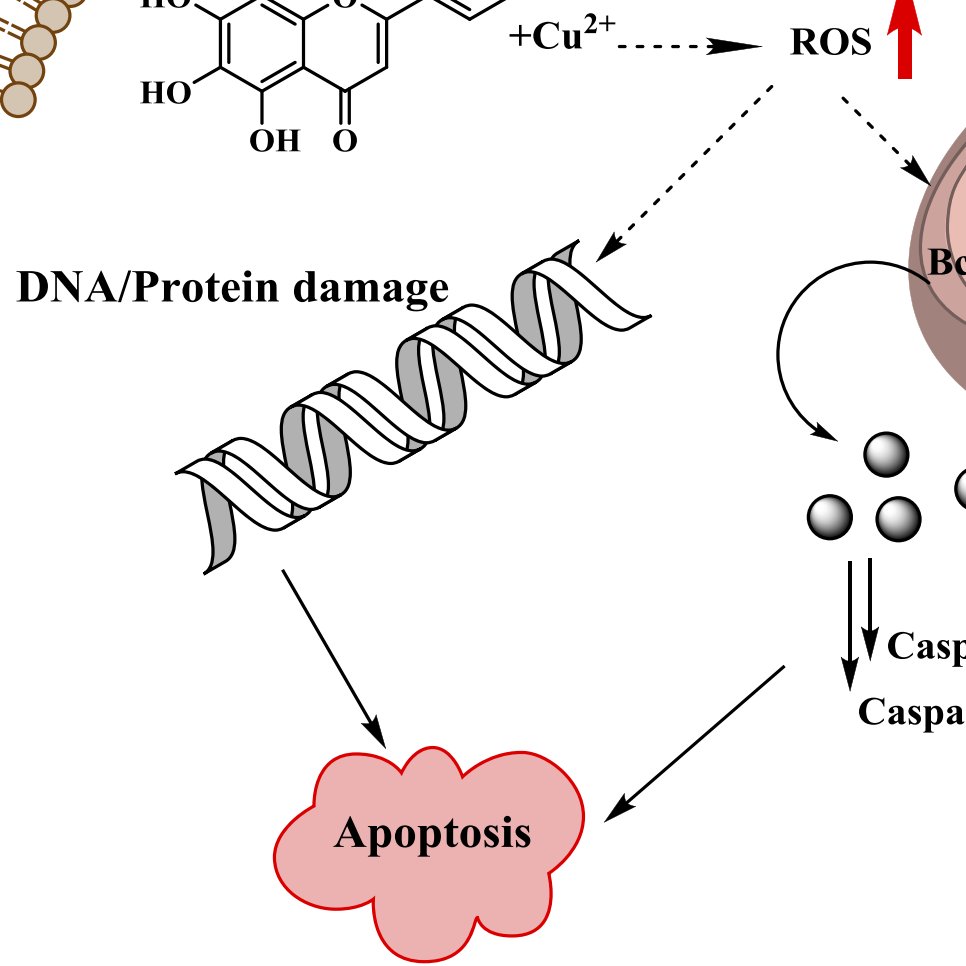

O

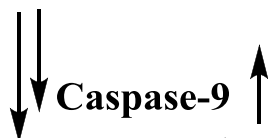

Caspase-3 $\uparrow$

Figure 10 Schematic diagram of the possible mechanism for baicalein induced apoptosis in MCF-7 cells based its prooxidant action.

Meanwhile, the capacity of baicalein- $\mathrm{Cu}$ (II) system to generate ROS such as hydroxyl radicals were examined by various methods. The progressively increased formation of TBA and DNPH reactive substances; the gradually increased fluorescence intensity and EPR signals accompanied by the increasing concentration of baicalin were detected (Figures 8 and 9). These direct evidences revealed that baicalein-Cu (II) system could produce hydroxyl radicals. Moreover, addition of $\mathrm{Neo}$ and $\mathrm{TU}$ to the reaction system of baicalin- $\mathrm{Cu}$ (II), there was a considerable decrease in TBA and DNPH reactive substances levels (Figure 9).
All of the above experimental results indicate that the generated ROS through the reduction of $\mathrm{Cu}$ (II)- $\mathrm{Cu}$ (I) by baicalin were responsible for the DNA and proteins oxidative degradation, which will lead to the death of MCF-7 cells.

In conclusion, all the above data support a model where baicalein induces selective death of MCF-7 cells through its ability to mobilize intracellular copper, resulting in the formation of a baicalein-copper complex able to engage in redox cycling thus generating ROS and inducing mitochondrialdependent apoptosis cell death; the proposed mechanism is depicted in Figure 10. 


\section{Acknowledgments}

This research was kindly supported by the National Natural Science Foundation of China (81703773); Natural Science Foundation of Jiangsu Province Administration of Traditional Chinese, China (YB2017101); the College Natural Science Research Program of Jiangsu Province, China (13KJB350001).

\section{Disclosure}

The authors declare no conflict of interest.

\section{References}

1. Angelova PR, Abramov AY. Functional role of mitochondrial reactive oxygen species in physiology. Free Radic Biol Med. 2016;100:81-85. doi:10.1016/j.freeradbiomed.2016.06.005

2. Liochev SI. Reactive oxygen species and the free radical theory of aging. Free Radic Biol Med. 2013;60:1-4. doi:10.1016/j.freeradbiomed. 2013.02.011

3. Luo B, Li B, Wang W, et al. Rosuvastatin alleviates diabetic cardiomyopathy by inhibiting NLRP3 inflammasome and MAPK pathways in a type 2 diabetes rat model. Cardiovasc Drugs Ther. 2014;28 (1):33-43. doi:10.1007/s10557-013-6498-1

4. Chio IIC, Tuveson DA. ROS in cancer: the burning question. Trends Mol Med. 2017;23(5):411-429. doi:10.1016/j.molmed.2017.03.004

5. Wu SJ, Yang YY, Li FP, et al. Chelerythrine induced cell death through ROS-dependent ER stress in human prostate cancer cells. Oncotargets Ther. 2018;11:2593-2601. doi:10.2147/OTT.S157707

6. Ullah MF, Ahmad A, Zubair H, et al. Soy isoflavone genistein induces cell death in breast cancer cells through mobilization of endogenous copper ions and generation of reactive oxygen species. Mol Nutr Food Res. 2011;55(4):553-559. doi:10.1002/mnfr.v55.4

7. Dai F, Yan WJ, Du YT, et al. Structural basis, chemical driving forces and biological implications of flavones as $\mathrm{Cu}$ (II) ionophores. Free Radic Biol Med. 2017;108:554-563. doi:10.1016/j.freeradbiomed. 2017.04.023

8. Hadi S, Asad S, Singh S, et al. Putative mechanism for anticancer and apoptosis-inducing properties of plant-derived polyphenolic compounds. IUBMB Life. 2000;50(3):167-171. doi:10.1080/152165 400300001471

9. Bao XZ, Dai F, Li XR, et al. Targeting redox vulnerability of cancer cells by prooxidative intervention of a glutathione-activated $\mathrm{Cu}$ (II) pro-ionophore: hitting three birds with one stone. Free Radic Biol Med. 2018;124:342-352. doi:10.1016/j.freeradbiomed.2018.06.021

10. Perron NR, García CR, Pinzón JR, et al. Antioxidant and prooxidant effects of polyphenol compounds on copper-mediated DNA damage. J Inorg Biochem. 2011;105(5):745-753. doi:10.1016/j.jinorgbio.2011. 02.009

11. Khan HY, Zubair H, Ullah MF, et al. A prooxidant mechanism for the anticancer and chemopreventive properties of plant polyphenols. Curr Drug Targets. 2012;13:1738-1749. doi:10.2174/138945012804545560

12. Farhan M, Khan HY, Oves M, et al. Cancer therapy by catechins involves redox cycling of copper ions and generation of reactive oxygen species. Toxins. 2016;8(2):37. doi:10.3390/toxins 8020037

13. Zubair H, Azim S, Khan HY, et al. Mobilization of intracellular copper by gossypol and apogossypolone leads to reactive oxygen species-mediated cell death: putative anticancer mechanism. Int J Mol Sci. 2016;17(6):973. doi:10.3390/ijms17060973

14. Ullah MF, Ahmad A, Khan HY, et al. The prooxidant action of dietary antioxidants leading to cellular DNA breakage and anticancer effects: implications for chemotherapeutic action against cancer. Cell Biochem Biophys. 2013;67:431-438. doi:10.1007/s12013-011-9303-4
15. Jain AK, Thanki K, Jain S. Novel self-nanoemulsifying formulation of quercetin: implications of pro-oxidant activity on the anticancer efficacy. Nanomed. 2014;10(5):959-969. doi:10.1016/j.nano.2013.12.010

16. Azmi AS, Bhat SH, Hanif S, et al. Plant polyphenols mobilize endogenous copper in human peripheral lymphocytes leading to oxidative DNA breakage: a putative mechanism for anticancer properties. FEBS Lett. 2006;580(2):533-538. doi:10.1016/j.febslet.2005.12.059

17. Liu H, Dong Y, Gao Y, et al. The fascinating effects of baicalein on cancer: a review. Int $J$ Mol Sci. 2016;17(10):1681. doi:10.3390/ ijms17101681

18. Zafar A, Singh S, Naseem I. Cytotoxic activity of soy phytoestrogen coumestrol against human breast cancer MCF-7 cells: insights into the molecular mechanism. Food Chem Toxicol. 2017;99:149-161. doi:10.1016/j.fct.2016.11.034

19. Sun YT, Wang CY, Meng Q, et al. Targeting P-glycoprotein and SORCIN: dihydromyricetin strengthens anti-proliferative efficiency of adriamycin via MAPK/ERK and $\mathrm{Ca}^{2+}$-mediated apoptosis pathways in MCF-7/ADR and K562/ADR. J Cell Physiol. 2018;233 (4):3066-3079. doi:10.1002/jcp.v233.4

20. Han X, Deng S, Wang N, et al. Inhibitory effects and molecular mechanisms of tetrahydrocurcumin against human breast cancer MCF-7 cells. Food Nutr Res. 2016;60(e):30616. doi:10.3402/fnr.v60.30616

21. Wang N, Ren D, Deng S, et al. Differential effects of baicalein and its sulfated derivatives in inhibiting proliferation of human breast cancer MCF-7 cells. Chem-Biol Interact. 2014;221:99-108. doi:10.1016/j. cbi.2014.08.003

22. Kavithaa K, Sumathi S, Padma PR. Intracellular uptake of PEG-funtionalized baicalein loaded iron oxide nanoparticles regulates apoptotic genes in triple negative breast cancer cells: mitochondrial pathway targeted therapy for breast cancer. J Clust Sci. 2017;28 (4):2057-2073. doi:10.1007/s10876-017-1204-2

23. El-Gogary RI, Gaber SAA, Nasr M. Polymeric nanocapsular baicalin: chemometric optimization, physicochemical characterization and mechanistic anticancer approaches on breast cancer cell lines. Sci Rep-UK. 2019;6:e11064.

24. Wang J, Li M, Cui XL, et al. Brevilin A promotes oxidative stress and induces mitochondrial apoptosis in U87 glioblastoma cells. Oncotargets Ther. 2018;11:7031-7040. doi:10.2147/OTT.S179730

25. Posadino AM, Cossu A, Giordo R, et al. Coumaric acid induces mitochondrial damage and oxidative-mediated cell death of human endothelial cells. Cardiovasc Toxicol. 2013;13(3):301-306. doi:10.10 07/s12012-013-9205-3

26. Xu MF, Xiong YY, Liu JK, et al. Asiatic acid, a pentacyclic triterpene in Centella asiatica, attenuates glutamate-induced cognitive deficits in mice and apoptosis in SH-SY5Y cells. Acta Pharmacol Sin. 2012;33 (5):578-587. doi:10.1038/aps.2012.3

27. Eremia SA, Chevalier-Lucia D, Radu GL, et al. Optimization of hydroxyl radical formation using $\mathrm{TiO}_{2}$ as photocatalyst by response surface methodology. Talanta. 2008;77:858-862. doi:10.1016/j. talanta.2008.07.056

28. Jing LQ, Xu YG, Xie M, et al. Three dimensional polyaniline/MgIn $\mathrm{S}_{4}$ nanoflower photocatalysts accelerated interfacial charge transfer for the photoreduction of $\mathrm{Cr}(\mathrm{VI})$, photodegradation of organic pollution and photocatalytic $\mathrm{H}_{2}$ production. Chem Eng J. 2019;360: 1601-1612.

29. Maurya DK, Devasagayam TPAJF. Antioxidant and prooxidant nature of hydroxycinnamic acid derivatives ferulic and caffeic acids. Food Chem Toxicol. 2010;48(12):3369-3373. doi:10.1016/j.fct.2010. 09.006

30. Kondakçı E, Özyürek M, Güçlü K, et al. Novel pro-oxidant activity assay for polyphenols, vitamins $\mathrm{C}$ and $\mathrm{E}$ using a modified CUPRAC method. Talanta. 2013;115:583-589. doi:10.1016/j.talanta.2013.06.006

31. Chen X, Wang J, Qin Q, et al. Mono-2-ethylhexyl phthalate induced loss of mitochondrial membrane potential and activation of Caspase 3 in HepG2 cells. Environ Toxicol Pharmacol. 2012;33(3):421-430. doi:10.1016/j.etap.2012.02.001 
32. Lee $\mathrm{CH}$, Shih YL, Lee MH, et al. Bufalin induces apoptosis of human osteosarcoma U-2 OS cells through endoplasmic reticulum stress, caspase-and mitochondria-dependent signaling pathways. Molecules. 2017;22(3):437. doi:10.3390/molecules22030437

33. Okada H, Mak TW. Pathways of apoptotic and non-apoptotic death in tumour cells. Nat Rev Cancer. 2004;4:592.

34. Hadi S, Ullah M, Azmi A, et al. Resveratrol mobilizes endogenous copper in human peripheral lymphocytes leading to oxidative DNA breakage: a putative mechanism for chemoprevention of cancer. Pharm Res. 2010;27(6):979-988.

35. Martin-Cordero C, Jose Leon-Gonzalez AJ, Manuel Calderon-Montano JM, et al. Pro-oxidant natural products as anticancer agents. Curr Drug Targets. 2012;13(8):1006-1028. doi:10.2174/138945012802009044

36. Wang Q, Qian YP, Dai F, et al. Ortho-dihydroxychalcones as cupric ion-dependent prooxidants: activity and mechanisms. Food Chem. 2013;141(2):1259-1266. doi:10.1016/j.foodchem.2013.04.022

37. Khan HY, Zubair H, Faisal M, et al. Plant polyphenol induced cell death in human cancer cells involves mobilization of intracellular copper ions and reactive oxygen species generation: a mechanism for cancer chemopreventive action. Mol Nutr Food Res. 2014;58 (3):437-446. doi:10.1002/mnfr.201300417
38. Zafar A, Singh S, Naseem I. Cu (II)-coumestrol interaction leads to ROS-mediated DNA damage and cell death: a putative mechanism for anticancer activity. J Nutr Biochem. 2016;33:15-27. doi:10.1016/ j.jnutbio.2016.03.003

39. Daniel KG, Chen D, Orlu S, et al. Clioquinol and pyrrolidine dithiocarbamate complex with copper to form proteasome inhibitors and apoptosis inducers in human breast cancer cells. Breast Cancer Res. 2005;7(6):R897-908.

40. Yang S, Liao Y, Li L, et al. Zeylenone induces mitochondrial apoptosis and inhibits migration and invasion in gastric cancer. Molecules. 2018;23(9):2149. doi:10.3390/molecules23092149

41. Dejean LM, Martinez-Caballero S, Manon S, et al. Regulation of the mitochondrial apoptosis-induced channel, MAC, by Bcl-2 family proteins. Biochim Biophys Acta. 2006;1762(2):191-201. doi:10.1016/j. bbadis.2005.07.002

42. Liu WJ, Yin YB, Sun JY, et al. Natural borneol is a novel chemosensitizer that enhances temozolomide-induced anticancer efficiency against human glioma by triggering mitochondrial dysfunction and reactive oxide species-mediated oxidative damage. Oncotargets Ther. 2018;11:5429-5439. doi:10.2147/OTT.S174498
OncoTargets and Therapy

\section{Publish your work in this journal}

OncoTargets and Therapy is an international, peer-reviewed, open access journal focusing on the pathological basis of all cancers, potential targets for therapy and treatment protocols employed to improve the management of cancer patients. The journal also focuses on the impact of management programs and new therapeutic agents and protocols on patient perspectives such as quality of life, adherence and satisfaction. The manuscript management system is completely online and includes a very quick and fair peer-review system, which is all easy to use. Visit http://www.dovepress.com/ testimonials.php to read real quotes from published authors. 